\title{
Opracowanie metodyki oznaczania BTEX w próbkach gleb z wykorzystaniem chromatografii gazowej z przystawką headspace
}

\begin{abstract}
W artykule opisano proces opracowania metodyki jakościowego i ilościowego oznaczania węglowodorów monoaromatycznych, do których należą benzen, toluen, etylobenzen i izomery ksylenu (BTEX), w próbkach gleby. Optymalizacja metodyki polegała na wykonaniu szeregu analiz wzorcowych i rzeczywistych próbek gleb skażonych jednopierścieniowymi węglowodorami aromatycznymi. Do oznaczania węglowodorów z grupy BTEX zastosowano metodę chromatografii gazowej z ekstrakcją do fazy nadpowierzchniowej, która pozwala w szybki i prosty sposób uzyskać informację o zawartości BTEX w próbkach środowiskowych, z pominięciem długotrwałego etapu przygotowania próbki. Opracowana metodyka została przetestowana na rzeczywistych próbkach gleb pobranych z terenów kopalń ropy naftowej, na których występowały doły urobkowe zawierające zastarzały odpad wiertniczy zanieczyszczony substancjami ropopochodnymi. Opracowaną metodykę wykorzystano również w kontroli przebiegu procesu bioremediacji substancji ropopochodnych w glebie (ex situ).
\end{abstract}

Słowa kluczowe: chromatografia gazowa, headspace, węglowodory monoaromatyczne, gleba, bioremediacja.

\section{Development of a headspace-gas chromatography method for the determination of BTEX in soil samples}

The article describes the process of developing qualitative and quantitative methods for the determination of monoaromatic hydrocarbons such as: benzene, toluene, ethylobenzene and xylene isomers (BTEX) in soil samples. Optimalization of the methodology consisted in carrying out a series of measurements for standard and real samples of soils, contaminated with monocyclic aromatic hydrocarbons. For the determination of BTEX hydrocarbons, a gas chromatographic method with extraction to the superficial phase was used, which allows to quickly and easily obtain the BTEX content of the environmental samples bypassing the long sample preparation stage. The developed methodology was tested on real soil samples taken from waste pits containing old drill waste contaminated with petroleum substances. The methodology was also used in the control of the process of bioremediation of petroleum substances in the soil (ex situ method).

Key words: gas chromatography, headspace, monoaromatic hydrocarbons, soil, bioremediation.

\section{Wprowadzenie}

Techniki headspace należą do jednych z najczęściej stosowanych technik izolacji lotnych związków organicznych w próbkach środowiskowych. Istnieje wiele różnych odmian analizy fazy nadpowierzchniowej opartych na wykorzystaniu zjawiska podziału międzyfazowego [7]. Ogólnie techniki te dzieli się na dwie podstawowe grupy: techniki statyczne, w których gaz i analizowana próbka pozostają względem siebie nieruchome, oraz techniki dynamiczne, w których jedna lub obydwie fazy ulegają przemieszczaniu [5]. Technika ekstrakcji do fazy nadpowierzchniowej polega na analizowaniu par będących w równowadze termodynamicznej z próbką w szczelnie zamkniętej fiolce i zaliczana jest do grupy tzw. technik ekstrakcji bezrozpuszczalnikowych, wskazanych podczas analizy lotnych analitów takich jak BTEX [7, 9].

BTEX jest skrótem stosowanym dla grupy lotnych związków organicznych takich jak: benzen, toluen, etylobenzen oraz o-, m- i p-ksylen [5]. Obecność węglowodorów monoaromatycznych w środowisku wynika głównie z zastosowania ich 
w przemyśle jako rozpuszczalników oraz w procesie otrzymywania różnego rodzaju produktów przemysłu organicznego, jak np.: smarów, farb, lakierów, tworzyw sztucznych, kauczuków, żywic, barwników czy klejów. Skażenie związkami zaliczającymi się do tej grupy związane jest również ze stosowanymi paliwami, w których występuje ich duże stężenie, choćby w benzynie czy produktach pochodnych, takich jak olej napędowy, smarowy czy opałowy. Poza tym obecność jednopierścieniowych węglowodorów aromatycznych w środowisku może być wynikiem działania przemysłu wydobywczego, przede wszystkim wydobycia ropy naftowej na danym terenie. Stanowi to poważne zagrożenie dla środowiska, jak i dla zdrowia publicznego [2]. Z tego powodu związki te zaliczono do grupy najważniejszych substancji zanieczyszczających branych pod uwagę przez organizacje zajmujące się ochroną środowiska oraz odgrywają one istotną rolę w ocenie skażenia środowiska przyrodniczego [2].

Wykorzystanie chromatografii gazowej połączonej z techniką headspace do identyfikacji węglowodorów monoaromatycznych stwarza zatem możliwość wykonywania szybkich i precyzyjnych oznaczeń w próbkach środowiskowych. Ponadto umożliwia wyeliminowanie pracochłonnego etapu wydzielania analitów z matrycy glebowej i zapobiega nadmiernym stratom lotnych węglowodorów, co w przypadku tradycyjnych metod przygotowania próbki skutkuje uzyskaniem dużych błędów pomiarowych.

\section{Opracowanie i walidacja metody analitycznej}

Oznaczanie węglowodorów z grupy BTEX najczęściej prowadzone jest metodami chromatografii gazowej z wykorzystaniem detekcji płomieniowo-jonizacyjnej GC-FID bądź masowej GC-MS [14]. Do analizy węglowodorów monoaromatycznych w próbkach gruntu użyto chromatografu Clarus 500 GC-FID z przystawką Headspace TurboMatrix 16, którym dysponuje Zakład Technologii Eksploatacji Płynów Złożowych INiG - PIB. W ramach opracowania metodyki badawczej oznaczania BTEX w próbkach gleb - określono optymalne parametry pracy chromatografu, takie jak: temperatura inżektora: $200^{\circ} \mathrm{C}$, temperatura detektora: $280^{\circ} \mathrm{C}$, przebieg temperaturowy pieca: $60^{\circ} \mathrm{C}$ - przebieg izotermiczny przez $5 \mathrm{mi}-$ nut, przyrost temperatury od $60^{\circ} \mathrm{C}$ do $100^{\circ} \mathrm{C}$ z szybkością $5^{\circ} \mathrm{C} / \mathrm{min}, 100^{\circ} \mathrm{C}$ - przebieg izotermiczny przez 10 minut. Rozdział chromatograficzny przeprowadzono na kolumnie Rt-TCEP (60 $\mathrm{m} \times 0,25 \mu \mathrm{m})$ wypełnionej 1,2,3-tris(2-cyjanoetoksy)propanem, charakteryzującym się wysoką polarnością.

Przed przystąpieniem do kalibracji urządzenia konieczne było ponadto określenie optymalnych warunków termostato-

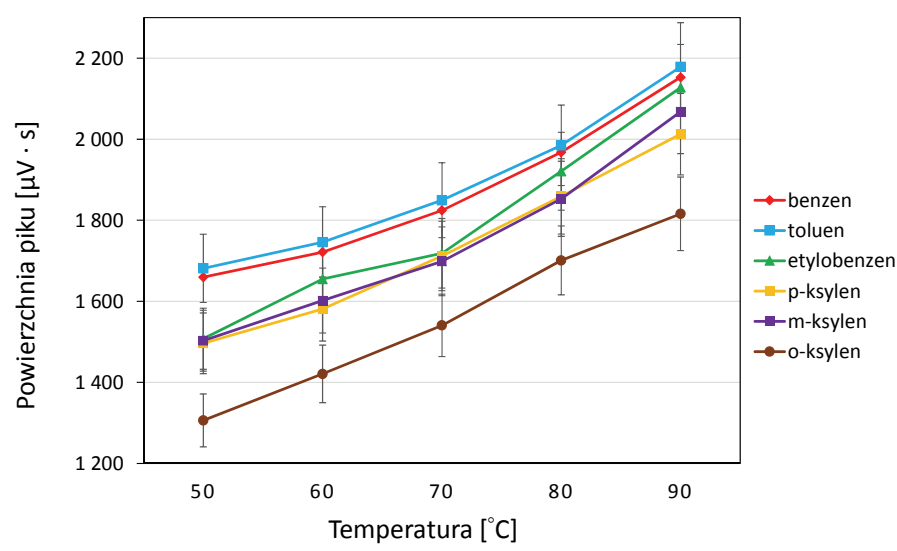

Rys. 1. Zależność pola powierzchni piku chromatograficznego od temperatury termostatowania w próbkach gleby o stężeniu $10 \mathrm{mg} / \mathrm{kg}$ s.m. każdego z węglowodorów BTEX ( $t=10 \mathrm{~min})$ wania próbek. Na podstawie specyfikacji kolumny chromatograficznej oraz danych literaturowych wytypowano przykładową temperaturę i czas termostatowania [11]. W celu weryfikacji informacji wykonano serię analiz wzorcowych próbek gleby o stężeniach $10 \mathrm{mg} / \mathrm{kg}$ s.m., na podstawie których możliwe było określenie najkorzystniejszej temperatury i czasu termostatowania próbki (rysunki 1 i 2) [3, 6, 8]. Analizując zależności powierzchni piku od temperatury i czasu termostatowania próbki, dla gleby wybrano temperaturę $90^{\circ} \mathrm{C}$ i czas 10 minut.

Kalibrację układu chromatograficznego pod względem oznaczania jednopierścieniowych węglowodorów aromatycznych w glebach [15] oparto na roztworach wzorcowych firm Restek i Supelco o stężeniach $200 \mu \mathrm{g} / \mathrm{ml}$ każdego składnika w metanolu o numerach odpowiednio 30051 oraz CRM48026, jak również o stężeniu $2000 \mu \mathrm{g} / \mathrm{ml}$ firmy Supelco o numerze CRM 47993. Wykorzystując roztwory wzorcowe, przygotowano serię dziewięciu próbek kalibracyjnych o stężeniach poszczególnych jednopierścieniowych węglowodorów aromatycznych w glebie równych: $0,1,2,5,10,20,50,100$ i $200 \mathrm{mg} / \mathrm{kg}$ s.m. Na podstawie

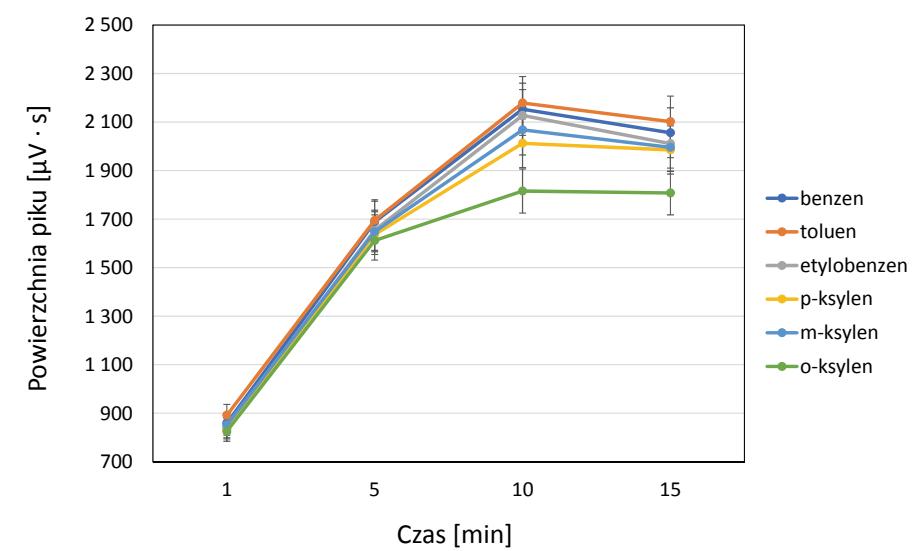

Rys. 2. Zależność pola powierzchni piku chromatograficznego od czasu termostatowania w próbkach gleby o stężeniu $10 \mathrm{mg} / \mathrm{kg}$ s.m. każdego z węglowodorów BTEX $\left(T=90^{\circ} \mathrm{C}\right)$ 
Tablica 1. Zestawienie krzywych kalibracyjnych stosowanych do obliczeń ilościowych BTEX w glebach oraz współczynników regresji

\begin{tabular}{|l|c|c|c|c|}
\hline \multicolumn{1}{|c|}{ Składnik } & $\begin{array}{c}\text { Równanie krzywej } \\
\text { kalibracyjnej (zakres stężeń } \\
0 \div 2 \mathrm{mg} / \mathrm{kg} \mathrm{s.m.)}\end{array}$ & $\begin{array}{c}\text { Równanie krzywej } \\
\text { kalibracyjnej (zakres stężeń } \\
2 \div 200 \mathrm{mg} / \mathrm{kg} \mathrm{s.m})\end{array}$ & $\begin{array}{c}\text { Współczynnik regresji } R^{2} \\
\text { (zakres stężeń } \\
0 \div 2 \mathrm{mg} / \mathrm{kg} \mathrm{s.m})\end{array}$ & $\begin{array}{c}\text { Współczynnik regresji } R^{2} \\
\text { (zakres stężeń } \\
2 \div 200 \mathrm{mg} / \mathrm{kg} \mathrm{s.m})\end{array}$ \\
\hline Benzen & $y=36,185 x-0,4717$ & $y=348,15 x-1043$ & 0,9995 & 0,9985 \\
\hline Toluen & $y=34,843 x+0,5025$ & $y=286,43 x-265,82$ & 0,9994 & 0,9986 \\
\hline Etylobenzen & $y=34,55 x-0,31$ & $y=218,24 x+427,03$ & 0,9998 & 0,9987 \\
\hline p-ksylen & $y=30,585 x-0,4517$ & $y=213,41 x+421,72$ & 0,9993 & 0,9982 \\
\hline m-ksylen & $y=30,585 x-0,785$ & $y=208,53 x+560,32$ & 0,9980 & 0,9979 \\
\hline o-ksylen & $y=29,855 x+0,2617$ & $y=191,92 x+419,32$ & 0,9998 & 0,9980 \\
\hline
\end{tabular}

przeprowadzonych analiz i danych uzyskanych w programie TotalChrom wykreślono dla każdego z węglowodorów z grupy BTEX krzywe kalibracyjne, będące zależnością powierzchni piku wyrażoną $\mathrm{w} \mu V \cdot s$ od stężenia wyrażonego $\mathrm{w} \mathrm{mg} / \mathrm{dm}^{3}$. Ze względu na szeroki zakres analizowanych stężeń krzywą wzorcową podzielono na dwa zakresy: $0 \div 2 \mathrm{mg} / \mathrm{kg}$ s.m. i $2,00 \div 200 \mathrm{mg} / \mathrm{kg}$ s.m. [14]. Otrzymane wyniki badań przedstawiono w tablicy 1 . W przypadku krzywych kalibracyjnych wykonywanych dla próbek gleby do ich opisu zastosowano wielomian I stopnia $y=a x+b$. Współczynnik regresji dla stężeń węglowodorów z grupy BTEX w zakresie $0 \div 2 \mathrm{mg} / \mathrm{kg}$ s.m. zawierał się w przedziale od 0,9980 do 0,9998 , a dla zakresu stężeń $2 \div 200 \mathrm{mg} / \mathrm{kg}$ s.m. - w przedziale od 0,9979 do 0,9986 . Wysokie wartości współczynników regresji analizowanych węglowodorów monoaromatycznych świadczą o dobrym dopasowaniu liniowym.

Po przeprowadzeniu optymalizacji metodyki oznaczania BTEX w próbkach gleb dokonano jej sprawdzenia. Na podstawie uzyskanych wyników testowanego wzorca o stężeniu każdego $\mathrm{z}$ analitów równym $20 \mathrm{mg} / \mathrm{kg}$ s.m. (10 analiz) obliczono średnie wartości stężeń, odchylenie standardowe oraz względne odchylenie standardowe [\%]. Przeprowadzone testy chromatograficznego oznaczania jednopierścieniowych wę- glowodorów aromatycznych we wzorcowych próbkach gleby wykazały stabilność testowanego układu chromatograficznego. Określone wartości względnego odchylenia standardowego, będące miarą precyzji metody analitycznej, zawierają się w granicach od 2,5767\% do 5,5526\%.

W wyniku doboru optymalnych warunków chromatograficznych uzyskano rozdział oznaczanych substancji we wzorcowej próbce gleby, który został przedstawiony na rysunku 3.

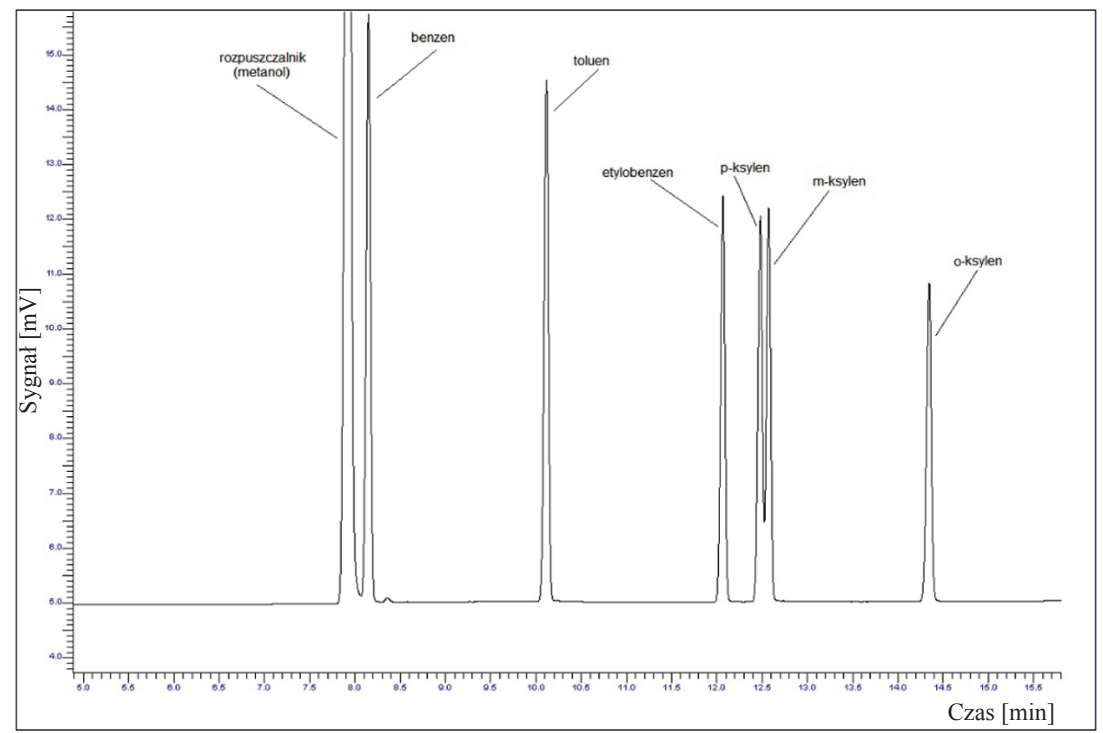

Rys. 3. Chromatogram rozdziału węglowodorów BTEX we wzorcowej próbce gleby o stężeniu węglowodorów monoaromatycznych równym $100 \mathrm{mg} / \mathrm{kg}$ s.m.

\section{Zastosowanie metodyki chromatograficznego oznaczania składników w próbkach środowiskowych}

Rzeczywisty materiał wykorzystywany do badań metodą chromatografii gazowej z ekstrakcją do fazy nadpowierzchniowej stanowiły próbki gleby pobrane z terenów kopalń ropy naftowej, zlokalizowanych w województwie małopolskim. Na terenie kopalń występowały doły urobkowe zawierające zastarzały odpad wiertniczy, skażony substancjami ropopochodnymi. Analizowane próbki pobrano z trzech różnych głębokości:
$0 \div 0,25$ m p.p.t.; $0,25 \div 1,00$ m p.p.t.; $1 \div 2,50$ m p.p.t. - zgodnie $\mathrm{z}$ rozporządzeniem Ministra Środowiska $\mathrm{z}$ dnia 1 września 2016 r. w sprawie sposobu prowadzenia oceny zanieczyszczenia powierzchni ziemi [16] - do szczelnie zamykanych pojemników, eliminując tym samym możliwość odparowania substancji lotnych i wtórnego zanieczyszczenia, oraz zabezpieczono je następnie przed działaniem promieni słonecznych. 
Ze względu na dużą lotność oznaczanych analitów pobrane próbki należało jak najszybciej dostarczyć do laboratorium i poddać analizie chromatograficznej.

W celu oznaczenia węglowodorów monoaromatycznych - na wadze analitycznej z dokładnością do 0,0001 g odważono próbkę gleby o masie około $6,5 \mathrm{~g}$, co w przeliczeniu na suchą masę gleby wynosiło około 5 g. Następnie próbkę gleby umieszczono w ampułce, którą szczelnie zamknięto za pomocą kapslownicy, i włożono do autosamplera przystawki. Próbkę przed analizą termostatowano przez 10 minut $\mathrm{w}$ temperaturze $90^{\circ} \mathrm{C}$. Ampułka była napełniana gazem nośnym (hel) przez 3 minuty, po czym za pomocą igły dozującej, podgrzanej do temperatury $95^{\circ} \mathrm{C}$, została pobrana próbka zdesorbowanych analitów gazowych, która przez li-

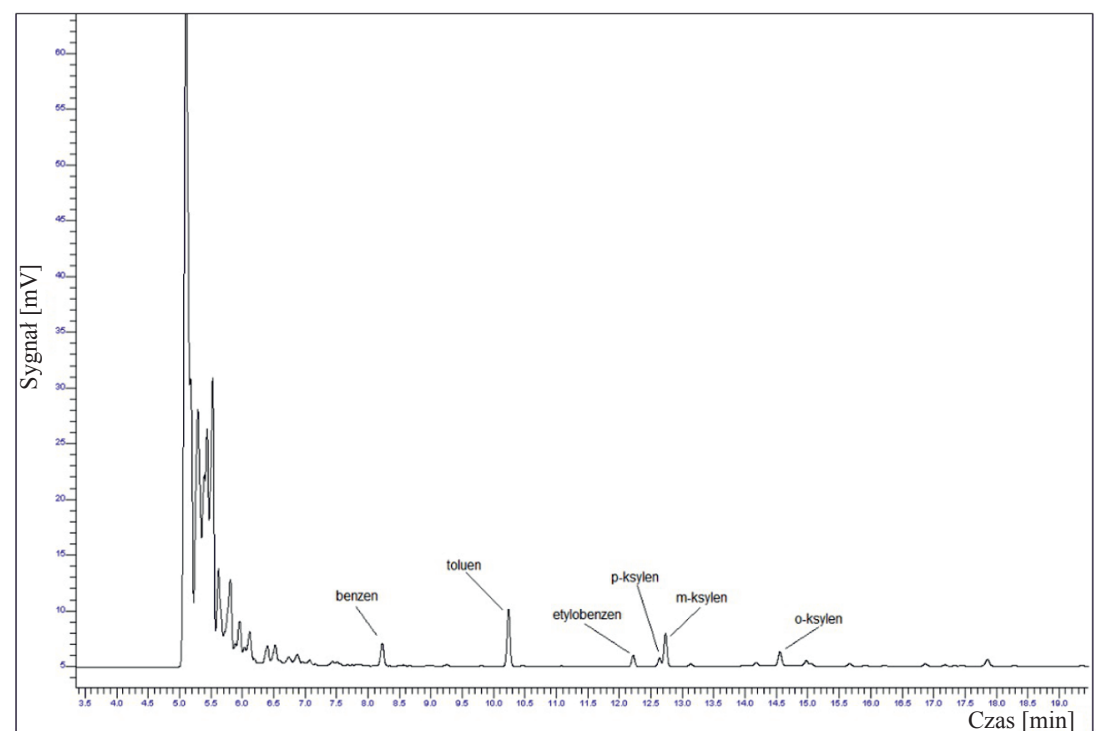

Rys. 4. Przykładowy chromatogram rozdziału substancji ropopochodnych w rzeczywistej próbce gleby przy odwiercie A pobranej z otworu nr 3, z głębokości $1,00 \div 2,50$ m p.p.t. nię transferową (temperatura $100^{\circ} \mathrm{C}$ ) była przesyłana do inżektora chromatografu. Czas nastrzyku wynosił 0,04 minuty $[1,4,11]$. Analizę chromatograficzną wykonano na chromatografie Clarus 500 GC-FID przy uprzednio ustalonych parametrach jego pracy. Uzyskane wyniki przeliczono na suchą masę gleby. Przykładowy chromatogram rozdziału zanieczyszczeń ropopochodnych w rzeczywistej próbce gleby pobranej z głębokości $1,00 \div 2,50$ m p.p.t. przy odwiercie A $\mathrm{z}$ otworu nr 3 przedstawiono na rysunku 4.

$\mathrm{Na}$ podstawie analizy chromatograficznej obliczono zawartość poszczególnych jednopierścieniowych węglowodorów aromatycznych (BTEX) w próbkach gleby. Próbki pobierano w okolicach trzech odwiertów: A, B i C, z trzech otworów na każdy odwiert, na trzech różnych głębokościach: $0 \div 0,25$ m p.p.t., $0,25 \div 1,00$ m p.p.t. i $1,00 \div 2,50$ m p.p.t. Otwór 1 w przypadku każdego z odwiertów znajdował się poza terenem dołu urobkowego, natomiast otwory 2 i 3 - na terenie dołów

urobkowych. Rozkład zawartości poszczególnych węglowodorów z grupy BTEX w próbkach gleby z odwiertów A, B i C z otworów o najmniejszym i największym stężeniu BTEX przedstawiono na rysunkach 5, 6 i 7 .

Wykonane oznaczenia węglowodorów z grupy BTEX w rzeczywistych próbkach gleb, pobranych z terenów kopalń ropy naftowej, na których występują doły urobkowe zawierające zastarzały odpad wiertniczy, skażony substancjami ropopochodnymi, wykazały, że ilościowy rozkład zawartości poszczególnych węglowodorów z grupy BTEX zależy od miejsca poboru próbki. W próbkach gleb pochodzących z terenów dołów urobkowych zlokalizowanych przy odwiertach A i C odnotowano znacznie wyższą zawartość jednopierścieniowych węglowodorów aromatycznych niż w próbkach $\mathrm{z}$ terenu dołu urobkowego przy odwiercie B. Sumaryczna zawartość BTEX w próbkach pobranych $\mathrm{z}$ terenów dołów urobkowych
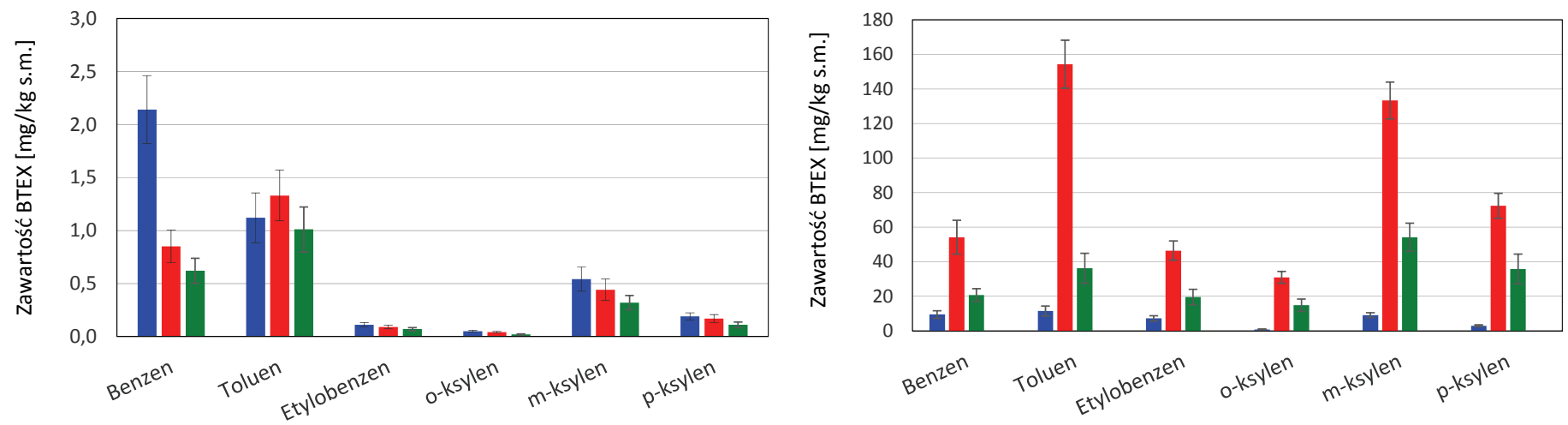

próbka gleby pobrana z otworu 1 przy odwiercie $A$ z głębokości 0,00-0,25 m p.p.t. - próbka gleby pobrana z otworu 1 przy odwiercie A z głębokości 0,25-1,00 m p.p.t. - próbka gleby pobrana z otworu 1 przy odwiercie A z głębokości 1,00-2,50 m p.p.t.

Rys. 5. Rozkład zawartości jednopierścieniowych węglowodorów aromatycznych (BTEX) w próbkach gleby pobranych z różnych głębokości otworów 1 i 2 zlokalizowanych w okolicy odwiertu A 


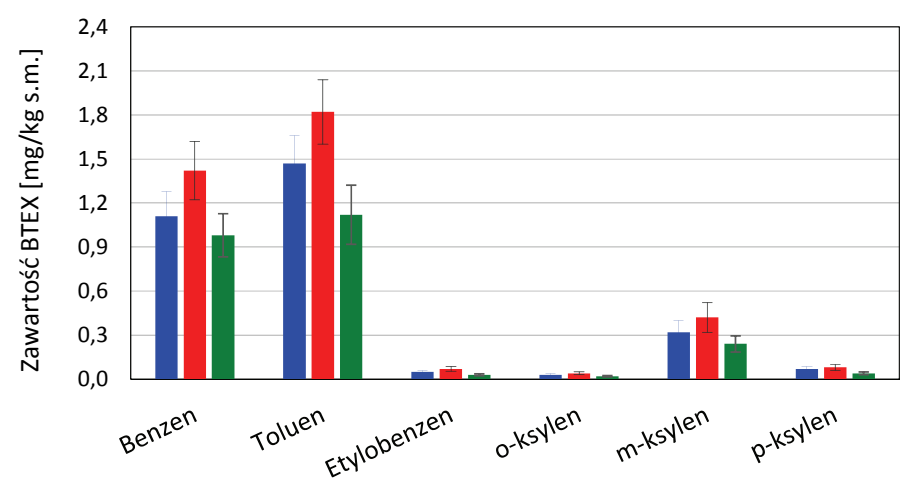

— próbka gleby pobrana z otworu 1 przy odwiercie B z głębokości 0,00-0,25 m.p.p.t. — próbka gleby pobrana z otworu 1 przy odwiercie B z głębokości 0,25-1,00 m.p.p.t. - próbka gleby pobrana z otworu 1 przy odwiercie B z głębokości 1,00-2,50 m.p.p.t.

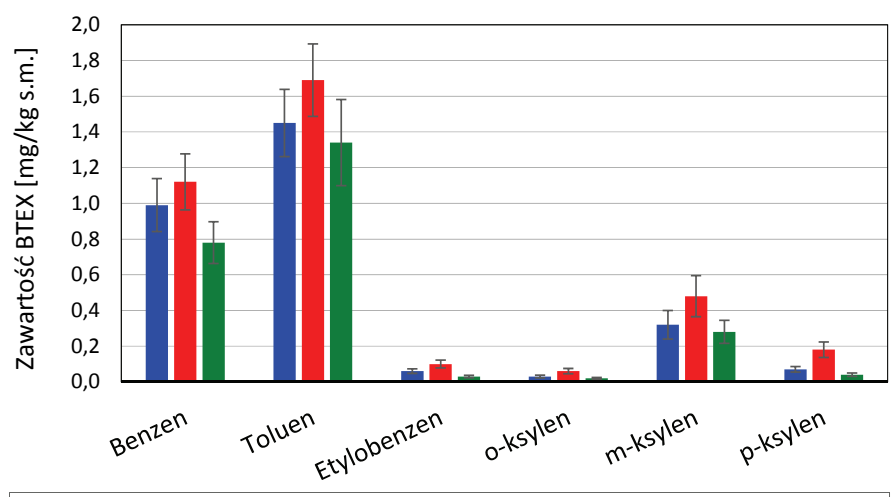

próbka gleby pobrana z otworu 2 przy odwiercie B z głębokości 0,00-0,25 m p.p.t. próbka gleby pobrana z otworu 2 przy odwiercie $B$ z głębokości 0,25-1,00 m p.p.t. n próbka gleby pobrana z otworu 2 przy odwiercie B z głębokości 1,00-2,50 m p.p.t.

Rys. 6. Rozkład zawartości jednopierścieniowych węglowodorów aromatycznych (BTEX) w próbkach gleby pobranych z różnych głębokości z otworów 1 i 3 zlokalizowanych w okolicy odwiertu B

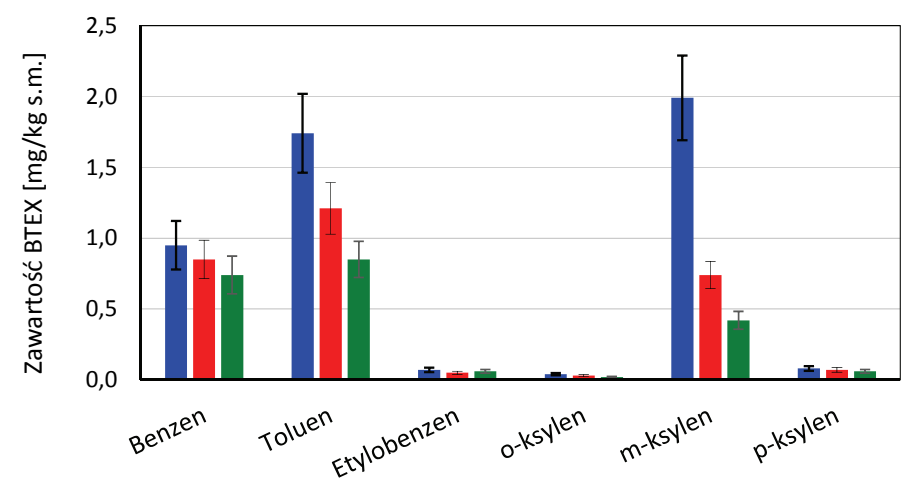

ص próbka gleby pobrana z otworu 1 przy odwiercie C z głębokości 0,00-0,25 m p.p.t. - próbka gleby pobrana z otworu 1 przy odwiercie $C$ z głębokości 0,25-1,00 m p.p.t. - próbka gleby pobrana z otworu 1 przy odwiercie C z głębokości 1,00-2,50 m p.p.t.

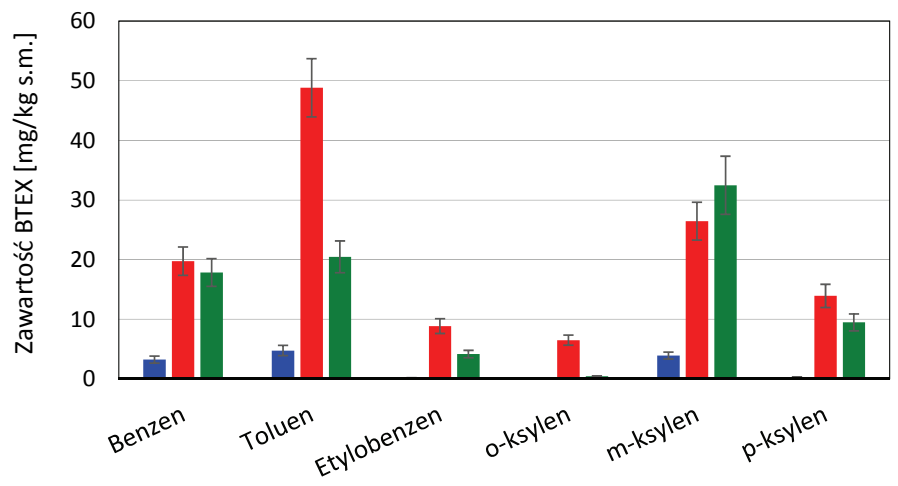

- próbka gleby pobrana z otworu 2 przy odwiercie $C$ z głębokości 0,00-0,25 m.p.p.t. - próbka gleby pobrana z otworu 2 przy odwiercie C z głębokości 0,25-1,00 m.p.p.t. - próbka gleby pobrana z otworu 2 przy odwiercie C z głębokości 1,00-2,50 m.p.p.t.

Rys. 7. Rozkład zawartości jednopierścieniowych węglowodorów aromatycznych (BTEX) w próbkach gleby pobranych z różnych głębokości z otworów 1 i 3 zlokalizowanych w okolicy odwiertu C

zlokalizowanych w pobliżu odwiertów A i C sięgała niekiedy kilkuset mg/kg s.m., podczas gdy ich zawartość przy odwiercie B nie przekraczała $10 \mathrm{mg} / \mathrm{kg}$ s.m. Wysokie stężenia węglowodorów z grupy BTEX w próbkach pobranych z głębokości $1,00 \div 2,50$ m p.p.t. wskazują na to, że zanieczyszczenie substancjami ropopochodnymi może występować jeszcze na znacznie większych głębokościach, gdzie zmniejszona jest przepuszczalność gleby dla tlenu atmosferycznego. Spośród oznaczanych związków dominującymi okazały się: benzen, toluen i m-ksylen, najmniejsze zawartości odnotowano natomiast dla etylobenzenu, p-ksylenu i o-ksylenu. Dzięki przeprowadzonym analizom z wykorzystaniem opracowanej metodyki oznaczania węglowodorów z grupy BTEX możliwe jest określenie poziomu skażenia terenów kopalń ropy naftowej, na których występują doły urobkowe zawierające zastarzały odpad wiertniczy skażony substancjami ropopochodnymi.

\section{Wykorzystanie opracowanej metodyki w monitorowaniu przebiegu procesu bioremediacji zanieczyszczeń ropopochodnych w glebie (metoda ex situ)}

Opracowana metodyka oznaczania węglowodorów z grupy BTEX z wykorzystaniem chromatografii gazowej z ekstrakcją do fazy nadpowierzchniowej została przetestowana laboratoryjnie w procesie monitorowania przebiegu bioremediacji jednopierścieniowych węglowodorów aromatycznych metodą ex situ.

W pierwszym etapie badań przeprowadzono badania próbki surowej, na podstawie których oznaczono zawartość poszczególnych jednopierścieniowych węglowodorów aromatycznych w glebie przeznaczonej do badań procesów bioremediacji. Proces bioremediacji zanieczyszczeń ropopochodnych obejmował dwa etapy: bioremediację podstawową i bioaugmentację $[11,13]$.

Jednym $z$ elementów procesu bioremediacji jest ocena zmian zawartości węglowodorów z grupy BTEX w glebie. 
W celu kontroli procesu oczyszczania gleby z jednopierścieniowych węglowodorów aromatycznych utworzono stanowisko badawcze monitoringu przebiegu bioremediacji BTEX w glebie pobranej z terenu kopalni ropy naftowej, na którym występują doły urobkowe zawierające zastarzały odpad wiertniczy. Badana gleba, w ilości około $50 \mathrm{~kg}$, zgromadzona została na hali w postaci pryzmy, którą umieszczono w tunelu foliowym, aby utrzymać wewnątrz stałą temperaturę na poziomie około $17 \div 25^{\circ} \mathrm{C}$. Glebę na stanowisku badawczym poddano procesowi bioremediacji podstawowej, stymulowanej poprzez napowietrzanie, regulację $\mathrm{pH}(7,5 \div 7,8)$ oraz zapewnienie odpowiedniej wilgotności gleby na poziomie $20 \div 25 \%$. Dla prawidłowego przebiegu procesu bioremediacji podstawowej zastosowano odpowiednie dawki wapna nawozowego i substancji odżywczych w stosunku N:P równym 8:1, mające na celu uzyskanie optymalnych wartości $\mathrm{C}: \mathrm{N}: \mathrm{P}$ na poziomie 100:8:1 [10, 12].

Po zakończeniu trwającego 30 dni procesu bioremediacji podstawowej rozpoczęto kolejny etap oczyszczania gleby, czyli bioaugmentację biopreparatem na bazie bakterii autochtonicznych, opracowanym w Zakładzie Mikrobiologii INiG - PIB. Bioaugmentację przeprowadzono w czterech seriach badawczych (I seria - 30 dni, II seria - 30 dni, III - seria $35 \mathrm{dni}$, IV seria - $40 \mathrm{dni}$ ), na podstawie których uzyskano wyniki badań wskazujące na znaczne obniżenie zawartości jednopierścieniowych węglowodorów aromatycznych w analizowanej glebie [12]. Porównanie zmian w zawartości jednopierścieniowych węglowodorów aromatycznych (BTEX) po przeprowadzeniu poszcze- gólnych etapów procesu bioremediacji na pryzmie metodą ex situ zamieszczono na rysunku 8.

Wykonane oznaczenia węglowodorów monoaromatycznych w próbce gleby poddanej procesowi bioremediacji wykazały, że spośród oznaczanych składników dominującymi są toluen i mksylen, natomiast w najmniejszej ilości występuje p-ksylen. Po okresie trwania bioremediacji podstawowej największy ubytek masy odnotowano dla benzenu $-14,1 \%$, a najmniejszy dla pksylenu $-7,7 \%$. W trakcie bioaugmentacji biopreparatem, trwającej łącznie 95 dni, uzyskano znaczne obniżenie zawartości węglowodorów monoaromatycznych $\mathrm{w}$ analizowanej próbce gleby - z 233,7 mg/kg s.m. do 71,0 mg/kg s.m. Najwyższy stopień biodegradacji węglowodorów monoaromatycznych w próbce gleby w trakcie całego procesu bioremediacji (125 dni) odnotowano w przypadku benzenu $(79,6 \%)$ i toluenu $(74,5 \%)$, natomiast najtrudniej biodegradowalny jest etylobenzen $(66,1 \%)$.

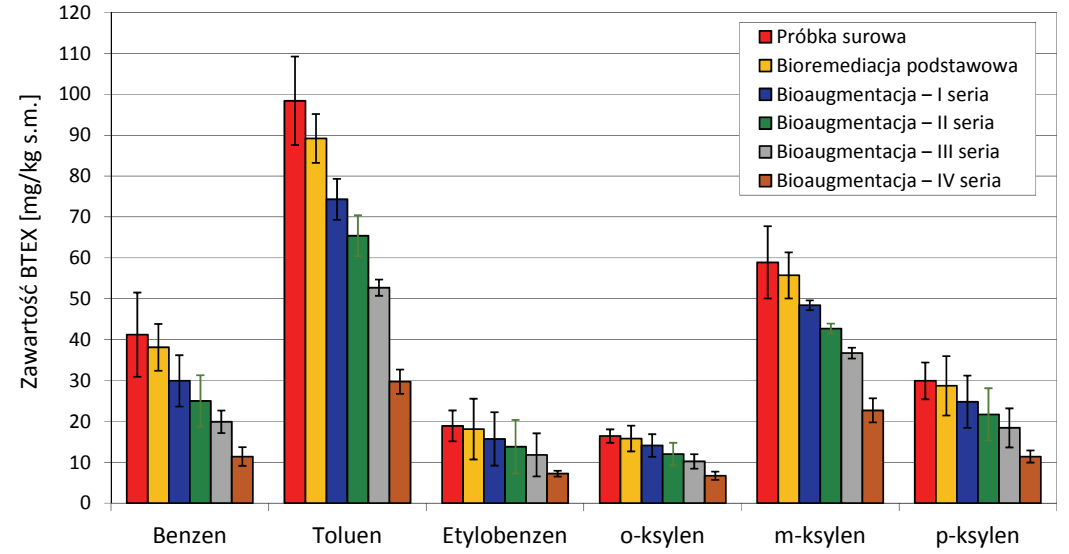

Rys. 8. Porównanie zmian zawartości jednopierścieniowych węglowodorów aromatycznych (BTEX) w poszczególnych etapach procesu oczyszczania na pryzmie (metoda ex situ)

\section{Podsumowanie}

1. Przemysł wydobywczy ropy i gazu, jak i cały przemysł petrochemiczny, generuje zanieczyszczenia węglowodorami, w tym także węglowodorami monoaromatycznymi (benzen, toluen, etylobenzen, izomery ksylenu). Węglowodory BTEX odgrywają istotną rolę w ocenie skażenia środowiska. Związki te zaliczane są do substancji toksycznych, w tym także kancerogennych. Dodatkowo ich właściwości chemiczne umożliwiają zarówno łatwą migrację w środowisku (woda, gleba, powietrze), jak i przedostawanie się do organizmu człowieka wraz z żywnością.

2. Przedstawiona metodyka oznaczania związków typu BTEX w próbkach gleb, z wykorzystaniem chromatografu Clarus 500 GC-FID firmy Perkin Elmer z przystawką TurboMatrix 16, jest skuteczna i szybka w realizacji dzięki pominięciu czasochłonnego etapu przygotowania próbki i eliminacji strat lotnych analitów. W porównaniu z tradycyjnymi metodami przygotowania próbek do analizy zanieczyszczeń ropopochodnych technikami chromatograficznymi pozwala ona na ograniczenie wpływu matrycy oraz wyeliminowanie konieczności stosowania wysokiej jakości rozpuszczalników.

3. Przeprowadzona walidacja układu chromatograficznego z wykorzystaniem certyfikowanych roztworów wzorcowych gwarantuje wysoką dokładność i powtarzalność uzyskanych wyników.

4. Dane analityczne dotyczące zawartości węglowodorów monoaromatycznych w próbkach gleb dostarczają cennych informacji o poziomie skażenia środowiska przyrodniczego. Szybkie wykrycie substancji niebezpiecznych pozwala na podjęcie odpowiednich kroków umożliwiających przeciwdziałanie dalszemu skażeniu środowiska. Oznaczono zawartości BTEX w próbkach gleb - na trzech głębokościach, zgodnie z Rozporządzeniem Ministra Środowiska 
z dnia 1 września 2016 r. w sprawie sposobu prowadzenia oceny zanieczyszczenia powierzchni ziemi. $\Sigma$ BTEX: na głębokości $0,00 \div 0,25 \mathrm{~m}$ p.p.t. zawierała się w zakresie od 2,94 $\pm 0,56 \mathrm{mg} / \mathrm{kg}$ s.m. do $287,84 \pm 26,59 \mathrm{mg} /$ kg s.m., na głębokości $0,25 \div 1,00$ m p.p.t. - w zakresie od 2,90 $\pm 0,45 \mathrm{mg} / \mathrm{kg}$ s.m. do $491,54 \pm 59,03 \mathrm{mg} /$ kg s.m., a na głębokości $1,00 \div 2,50$ m p.p.t. - w zakresie od 2,12 $\pm 0,33 \mathrm{mg} / \mathrm{kg} \mathrm{s.m}$. do $223,89 \pm 20,15 \mathrm{mg} / \mathrm{kg} \mathrm{s.m}$.

5. W wyniku badań bioremediacji jednopierścieniowych węglowodorów aromatycznych w analizowanej glebie uzyskano obniżenie zawartości $\Sigma$ BTEX z 263,70 mg/kg s.m. do $71,00 \mathrm{mg} / \mathrm{kg} \mathrm{s.m}$.

6. Opracowana metodyka pozwala na ilościowe i jakościowe oznaczenie poszczególnych węglowodorów z grupy BTEX w glebie zanieczyszczonej substancjami ropopochodnymi, zobrazowanie szybkości procesu bioremediacji oraz określenie stopnia biodegradacji BTEX uzyskanego dzięki zastosowaniu biopreparatu. Ponadto pozwala ona również na uchwycenie zmian zawartości jednopierścieniowych węglowodorów aromatycznych podczas przebiegu ich biodegradacji w kolejnych etapach oczyszczania.

7. Wykorzystanie opracowanej metodyki do analizy rzeczywistych próbek gleb pobranych z terenów kopalń ropy naftowej, na których występowały doły urobkowe zawierające zastarzały odpad wiertniczy skażony substancjami ropopochodnymi, oraz do kontroli procesu bioremediacji zanieczyszczeń ropopochodnych w glebie potwierdza przydatność prezentowanej metody.

Prosimy cytować jako: Nafta-Gaz 2018, nr 3, s. 201-207, DOI: 10.18668/NG.2018.03.03

Artykuł nadesłano do Redakcji 14.11.2017 r. Zatwierdzono do druku 9.02.2018 r.

Artykuł powstał na podstawie pracy statutowej pt.: Opracowanie metodyki oznaczania BTEX w próbkach środowiskowych z wykorzystaniem chromatografii gazowej z przystawka headspace - praca INiG - PIB na zlecenie MNiSW; nr zlecenia: 0047/KE/17, nr archiwalny: DK-4100-0034/17.

\section{Literatura}

[1] Balseiro-Romero M., Monterroso C.: A Headspace-Analysis Approach to Assess the Sorption of Fuel Volatile Compounds by Soils. Soil Science Society of America Journal, Abstract - Soil Chemistry 2013, vol. 77, nr 3, s. 800-808.

[2] Bolden A.L., Kwiatkowski C.F., Colborn T.: New Look at BTEX: Are Ambient Levels a Problem? Environmental Science \& Technology, Environ. Sci. Technol. 2015, vol. 49, s. 5261-5276.

[3] Flórez Menéndez J.C., Fernández Sánchez M.L., Fernández Martinez E., Sánchez Uria J.E., Sanz-Medel A.: Static headspace, solid-phase microextraction and headspace solid-phase microextraction for BTEX determination in aqueous samples by gas chromatography. Analytica Chimica Acta 2000, vol. 415, nr 1-2, s. 9-20.

[4] Górska S., Delis M., Chaber P.: Zastosowanie statycznej techniki headspace GC-MS do oznaczania benzenu, toluenu, etylobenzenu i ksylenu w glebie i roślinach. Przemysł Chemiczny 2012, vol. 91, nr 4, s. 569-573.

[5] Janiga M., Kania M.: Oznaczanie związów typu BTEX w wodach metoda chromatografii gazowej, z zastosowaniem techniki Purge and Trap. Nafta-Gaz 2011, nr 10, s. 729-735.

[6] Jing-fu Liu, Ning Li, Gui-bin Jiang, Jie-min Liu, Jan Ake Jönsson, Mei-juan Wen: Disposable ionic liquid coating for headspace solid-phase microextraction of benzene, toluene, ethylbenzene, and xylenes in paints followed by gas chromatography-flame ionization detection. Journal of Chromatography A 2005, vol. 1066, nr 1-2, s. 27-32.

[7] Kolb B., Ettre L.S.: Static headspace-gas chromatography: theory and practice. Wiley-Interscience, New Jersey 2006.

[8] Pavlova A., Stoyanova O., Ivanova P., Dimova T.: Uncertainty Estimation Related to Analysis of Volatile Aromatic Hydrocarbons by Static Headspace Gas Chromatography. Journal of Chromatographic Science 2014, vol. 52, s. 567-572.

[9] Spria Ana C., Garcia-Sarrió Maria J., Ruiz-Matute Ana I., Sanz Maria L.: Chapter Nine - Headspace Techniques for Volatile Sampling. Comprehensive Analytical Chemistry 2017, vol. 76, s. $255-278$.

[10] Steliga T.: Biodegradacja odpadów wiertniczych zanieczyszczonych substancjami ropopochodnymi. Nafta Gaz 2009, nr 5, s. 384-391.

[11] Steliga T.: Bioremediacja odpadów wiertniczych zanieczyszczonych substancjami ropopochodnymi ze starych dolów urobkowych. Prace Instytutu Nafty i Gazu 2009, nr 163.

[12] Steliga T.: Ocena efektywności biodegradacji węglowodorów ropopochodnych $w$ zastarzatym odpadzie z dotu urobkowego Graby-59 w warunkach przemystowych metoda in-situ. Nafta-Gaz 2014, nr 6, s. 351-364.

[13] Steliga T., Kapusta P., Jakubowicz P.: Biodegradacja ex situ gruntu z klasycznych gazowni skażonego weglowodorami ropopochodnymi. Wiertnictwo Nafta Gaz 2007, t. 24, z. 1, s. 475-486.

[14] Wiśniecka M., Holewa-Rataj J.: Optymalizacja strategii wzorcowania $w$ analizie zawartości lekkich węglowodorów w próbkach stałych metoda chromatografi gazowej z ekstrakcja do fazy nadpowierzchniowej (HS-GC-FID). Nafta-Gaz 2016, nr 9, s. 736-741, DOI: 10.18668/NG.2016.09.08.

[15] Zhou Y.Y., Yu J.F., Yan Z.G., Zhang C.Y., Xie Y.B., Ma L.Q., Gu Q.B., Li F.S.: Application of portable gas chromatographyphoto ionization detector combined with headspace sampling for field analysis of benzene, toluene, ethylbenzene and xylene in soils. Environ Monit Assess 2013, vol. 185, no. 4, s. 3037-3048.

\section{Akty prawne i normatywne}

[16] Rozporządzenie Ministra Środowiska z dnia 1 września 2016 r. $\mathrm{W}$ sprawie sposobu prowadzenia oceny zanieczyszczenia powierzchni ziemi (Dz.U. z 2016 r., poz. 1395).

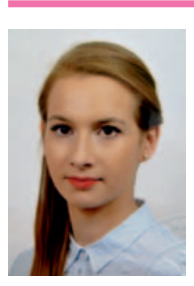

Mgr Katarzyna WOJTOWICZ

Specjalista inżynieryjno-techniczny w Zakładzie Technologii Eksploatacji Płynów Złożowych Instytut Nafty i Gazu - Państwowy Instytut Badawczy ul. Lubicz $25 \mathrm{~A}$

31-503 Kraków

E-mail:katarzyna.wojtowicz@inig.pl 